\title{
Costing systems \& variance analyses at the Carpenter \& Millbridge Ltd. Welding Alloys business unit : a case study
}

Citation for published version (APA):

Vergauwen, P. G. M. C. (2002). Costing systems \& variance analyses at the Carpenter \& Millbridge Ltd. Welding Alloys business unit : a case study. METEOR, Maastricht University School of Business and Economics. METEOR Research Memorandum No. 047 https://doi.org/10.26481/umamet.2002047

Document status and date:

Published: 01/01/2002

DOI:

10.26481/umamet.2002047

Document Version:

Publisher's PDF, also known as Version of record

Please check the document version of this publication:

- A submitted manuscript is the version of the article upon submission and before peer-review. There can be important differences between the submitted version and the official published version of record.

People interested in the research are advised to contact the author for the final version of the publication, or visit the DOI to the publisher's website.

- The final author version and the galley proof are versions of the publication after peer review.

- The final published version features the final layout of the paper including the volume, issue and page numbers.

Link to publication

\footnotetext{
General rights rights.

- You may freely distribute the URL identifying the publication in the public portal. please follow below link for the End User Agreement:

www.umlib.nl/taverne-license

Take down policy

If you believe that this document breaches copyright please contact us at:

repository@maastrichtuniversity.nl

providing details and we will investigate your claim.
}

Copyright and moral rights for the publications made accessible in the public portal are retained by the authors and/or other copyright owners and it is a condition of accessing publications that users recognise and abide by the legal requirements associated with these

- Users may download and print one copy of any publication from the public portal for the purpose of private study or research.

- You may not further distribute the material or use it for any profit-making activity or commercial gain

If the publication is distributed under the terms of Article $25 \mathrm{fa}$ of the Dutch Copyright Act, indicated by the "Taverne" license above, 


\title{
Costing Systems \& Variance Analyses at the Carpenter \& Millbridge Ltd. Welding Alloys Business Unit - a case study -
}

\author{
Dr. Philip Vergauwen \\ Universiteit Maastricht \\ Faculty of Economics \& Business Administration \\ $M A R C$, Accounting \& Information Management Section \\ P.O. Box 616 \\ 6200 MD Maastricht (The Netherlands) \\ p.vergauwen@berfin.unimaas.nl
}

December, 2002

\begin{abstract}
This case study illustrates how standard or traditional costing systems can reveal information that e.g. ABC methods would reveal, if appropriate variances are calculated. Variance analysis on disaggregated and timely information not only allows for timely corrective action, but it can also determine how e.g. set-up time related to smaller batches should be absorbed. Variance analysis could also indicate whether an alternative raw material is economically feasible or how a product's cost might reflect the use of alternate production facilities. Whereas much of such information would be translated into cost drivers when applying $\mathrm{ABC}$, extended variance analysis could also bring this information to the surface in a "traditional" costing system.
\end{abstract}




\section{Content}

Introduction

1. The Standard Run Quantity Variance

2. The Method Variance

3. The Material Substitution Variance

4. Sales \& General Administration

5. Sales \& Revenues

Assignments

Related Literature

p. 2

p. 4

p.6

p.7

p.8

p. 8

p. 9

p.11

\section{Introduction}

Carpenter \& Millbridge is a manufacturer of industrial welding alloys. The company uses its costing system and variance analyses as important business tools to target problem areas so it can develop solutions for continuous improvement. The company's costing-related tools include:

\section{Disaggregated product line information}

Carpenter \& Millbridge has been divided into Business Units (BU's) along product lines. The welding alloys business unit is one of these BU's. Earnings statements are developed for each BU and variances are shown as a percentage of production. If production variances exceed $5 \%$, the BU managers are required to provide an explanation and to put together a plan of action to correct the detected problems. To help the process, a plant accountant has been assigned to each BU. As a result of these steps, each unit is able to take a much more pro-active approach to variance analysis.

\section{Timely product cost information}

In the past, variances were reported only at month-end, but often a particular job already would have been off the shop floor for three or more weeks. Hence, when management questioned the variances, it was too late to review the job. Now, exception reports are generated the day after the last part has been manufactured. Any jobs with variances greater than $\varepsilon 1.000$ are displayed on this report. These reports are distributed to the managers, planners or schedulers and plant accountants, which permits people to ask questions while the job is still fresh in everyone's mind.

This leads to:

3. Timely corrective action 
Because each job is "costed" (transferred out of work-in-progress and into finished-goods) 10 days after the job has closed, there is adequate time for necessary corrective action. For example, investigating a large material quantity variance might reveal that certain defective finished parts were not included in the final tally of finished goods. Such timely information would allow management to decide whether to rework these parts or to increase the size of the next job. This kind of corrective action was not possible when variances were provided at the end of each month.

\section{Effective control system}

Summary reports are run weekly, beginning the second week of each month, to show each variance in total euro's as well as each variance by product line and each batch within the product line. In addition, at month-end, the database is up-dated with all variance-related information. As a result, business unit managers can review variances by part number, by job, or by high euro volume.

\section{Employee training and empowerment.}

Meetings are held regularly with the employees to explain variances and earnings statements for their $\mathrm{BU}$, thereby creating a more positive atmosphere in which the business unit team can work. These meetings help employees understand that management decisions are based on the numbers discussed and that if erroneous data are put into the system, then erroneous decisions may be made. For example, a machine may not be running efficiently. An operator may clock off the job so that his or her efficiency does not look bad. Because the machine's efficiency is not adversely impacted, no maintenance is done to that machine and the inefficiency continues. In addition, because the operator is not charging his or her cost to a job, the cost is being included in indirect labour and manufacturing costs increase. If the operator had reported the hours correctly, management would have questioned the problem and the machine would have been fixed or replaced based on how severe the problems were.

In addition to the aforementioned innovations that Carpenter \& Millbridge has made to adapt its costing system to its particular business environment, the company has created the following new variances:

1. the standard run quantity variance (SRQV) to explain situations where the size of a lot is less than the optimal batch quantity.

2. the method variance (MV) to assess situations where different machines can be used for the same job. 
3. the material substitution variance (MSV) to evaluate the feasibility of alternative raw materials.

Exhibits 1 and 2 (in appendix ${ }^{1}$ ) provide the production and cost data for the year ended. Per set-up and per machine the welding alloys business unit can produce up to 2.000 units. The business unit uses two machines. The older machine is of the SD70-X type. It has the same capacity as the new machine (SD95-XL) but requires more direct labour per machine hour than the newer machine and it can produce fewer units per machine hour. Both machines have been in operation during the past year, but the older machine (SD70-X) was switched on only when the SD95-XL could not cope with the planned production (see exhibit 2), i.e. whenever the weekly production exceeded 10.000 units.

Weekly machine maintenance costs amounted to a fixed $\varepsilon$ 300,00 (in total for the two machines) and the wage rate was $\varepsilon 10,00$ per labour hour throughout the whole year ended. During the past year 6 full-time equivalents of production labour were hired. Based on a 40-hour work-week, this amounts to a production labour capacity of 11.520 labour hours. Each the SD-95-XL and the older SD70-X have a normal yearly capacity of 9.600 machine hours in total .

\section{The Standard Run Quantity Variance (SRQV)}

The SRQV represents the amount of set-up cost that was not recovered because the batch size was smaller than the earlier determined optimal batch size. This optimal capacity equals the daily machine capacity of 2.000 units of production on both machines (SD70-X and SD95-XL), whence one set-up per day per machine would be optimal. Because set-up costs are included in the (indirect) labour hours, producing a smaller quantity than the standard batch quantity is likely to create an unfavourable labour efficiency variance (LEV). Unless, however, the impact of actual production inefficiencies is separated from setup-related inefficiencies, the LEV reflects the combined impact of these two causes of inefficiencies and is not really useful for taking the necessary corrective action.

Consider the following example:

\section{Carpenter \& Millbridge Ltd. - Welding Alloys BU Example 1 SRQV: Facts and Workings}

- Standard labour time per unit (hours)

- Standard production time ${ }^{3}$ (MH/unit)

\begin{tabular}{ccc} 
Set-up & Production & Total \\
\hline $4^{2}$ & $0,02^{4}$
\end{tabular}

\footnotetext{
${ }^{1}$ Data also available on diskette: C\&M WA BU.xls

2 Company's estimate.

${ }^{3}$ Company's estimate for machine hours per unit of production based on the new machine (SD95-XL).

${ }^{4}$ Company's estimate for direct labour hours per unit of production and given the optimal batch size (2.000 units).
} 
- Standard DLH per unit ${ }^{5}$ (DLH/unit)

- Standard (optimal) batch size (units)

- Standard time per unit (hours/unit)

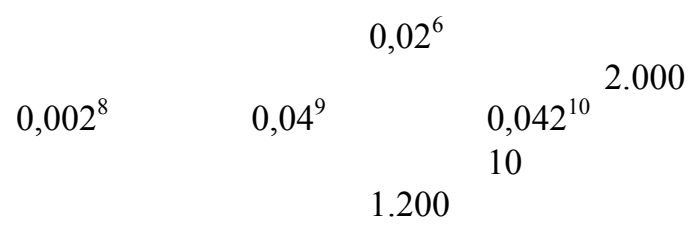

- Actual production (units)

- Actual set-up labour time (hours)

4

- Actual total direct labour time (hours)

- Actual machine time on SD95-XL

Calculations:

If SRQV is determined:

- budgeted labour costs:

(U)

- SRQV:

$(24+0,002 * 1.200) * 10$

264

$(4-2,40) * 10$

16

- LEV:

$(28-28) * 10$

- Accrued payroll (actual labour cost): $\quad(24+4) * 10$

If SRQV is NOT determined:

- budgeted labour costs:

$(26.4) * 10$

- LEV:

$28-(1.200 \div 0,022) * 10$

264

- Accrued payroll (actual labour cost): $\quad(24+4) * 10$

$\underline{16(\mathrm{U})}$

280

\section{The Method Variance (MV)}

A method variance occurs when more than one machine can be used to manufacture a product. For example, the welding alloys BU of Carpenter \& Millbridge has a newer machine (SD95-XL) that it normally would expect to use to manufacture a product, so its standards would be based on such new machines. Yet, the BU also keeps, as a back-up, an older and less efficient machine (SD70-X) that can also manufacture the same product but would require more inputs in the form of machine and labour hours. In order to illustrate this example, consider the company's estimate for the amount of direct labour per unit of production 1/30. As a result, the method variance becomes pertinent because the LEV (labour efficiency variance) from operating the older machines could potentially include the following two impacts. First an older machine may need additional labour hours to perform the same task, and the additional hours would be reflected in the LEV. Second, the LEV would include the workers' efficiency or the lack thereof on the older machine. The usefulness of calculating or extracting the Method Variance (MV), can be illustrated by analysing example 2, where the analysis shows that labour efficiency exceeded standards, although total direct labour costs exceeded the standard amount as calculated on the basis of using the new machine SD95-XL.

\footnotetext{
${ }^{5}$ Direct labour per unit of production based on the new machine (SD95-XL).

${ }^{6}$ Company's estimate based on using the SD95-XL machine.

${ }^{7}$ This holds for both the SD70-X and the SD95-XL machines.

${ }^{8}$ Standard set-up time (4 hours) devided by the standard production per batch ( 2.000 units).

${ }^{9}$ Sum of the standard direct labour and the machine production time.

${ }^{10}$ Sum of the standard set-up time and the standard production time per unit.
} 


\section{Carpenter \& Millbridge Ltd. - Welding Alloys BU \\ Example 2 \\ Method Variance (MV): Facts \& Workings}

- SD95-XL:

- Labour wage rate per hour:

standard DLH needed for one unit (minutes)

1,20

10

- Actual quantity produced on SD70-X (units):

- Actual direct labour hours used to make 1.200 units:

- Actual direct labour costs $(\varepsilon)$ :

Calculations:

If the MV is calculated:

- Standard DL cost for 1.200 units:

- MV:

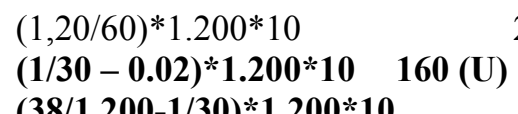

- LEV:

$(38 / 1.200-1 / 30) * 1.200 * 10$

- Actual direct labour costs:

If the MV is NOT calculated:

- Standard DL cost for 1.200 units:

- LEV:

- Actual direct labour costs:

$$
\begin{array}{cr}
(1,20 / 60) * 1.200 * 10 & 240 \\
(\mathbf{3 8} / \mathbf{1 . 2 0 0}-\mathbf{1 , 2 0 / 6 0 )} * \mathbf{1 . 2 0 0} * \mathbf{1 0} & \mathbf{1 4 0 ( U )}^{240} \\
380
\end{array}
$$

\section{The Material Substitution Variance (MSV)}

The MSV assumes perfect or near substitutability of raw materials and measures the loss or gain in material costs when a different raw material is used as a substitute for the material designated in the job sheet. Substitutions may be made for many reasons. For example, the designated material may not be available or may not be available in small-enough quantities, or the company may want to use up material it purchased for a product that is discontinued.

In the case of the welding alloys business unit, raw material $\mathrm{R}$ comes cheaper than raw material $\mathrm{S}$. The price of material $\mathrm{R}$ (per kilogram) is $\varepsilon 0,95$, whereas material $\mathrm{S}$ comes at $\varepsilon 1,075$ per kilogram. The problem now is that the supplier of both raw materials can supply a maximum of 1.850 kilograms of material $\mathrm{R}$ per set of 4 weeks (month), allowing a maximum production of 37.000 units. Carpenter\& Millbridge, therefore always order this amount, and whenever in a particular month the whole supply of material $\mathrm{R}$ is not used, it is kept for production in the following month ${ }^{11}$. Sometimes, however, as exhibit 3 (in appendix ${ }^{12}$ ) shows, an extra amount of material $\mathrm{S}$ is to be ordered such that monthly planned production can go ahead. Both materials $\mathrm{R}$ and $\mathrm{S}$ are used at a standard (budgeted) rate of 0,05 kilograms per unit of production. Material usage variances are believed to be minimal and are, therefore, neglected.

\footnotetext{
11 There were no raw material inventories at the beginning of the year.

12 See also diskette C\&M WA BU.xls
} 
The usefulness of MSV can be illustrated by analysing the data in example 3. Both materials R and S can be used to manufacture the product. Material $\mathrm{R}$ is the material designated but materials $\mathrm{S}$ and $\mathrm{R}$ are substitutes. Suppose material $\mathrm{S}$ is used because $\mathrm{R}$ is not available and a valued costumer needs a rush job.

\section{Carpenter \& Millbridge Ltd. - Welding Alloys BU Example 3 \\ MSV: Facts and Workings}

- Price per kilogram of material $\mathrm{R}$

$\varepsilon 0,95$

- Price per kilogram of material S

- Standard material quantity to make 100 units (kilograms)

- Actual quantity produced (units)

- Actual kilograms used

$\mathrm{R}$

Calculations:

If MSV is determined:

- standard cost raw material (R) used:

- MEV:

- MSV-price:

- MSV-efficiency:

- MSV-total:

$100 * 0,95$

$(80 * 0,95+20 * 1,075)-95$

$(19-20) * 1,075$

$(80 * 0,95+19 * 1,075)$

- Actual costs materials used:

$(100 * 0,95)$

$(80 * 0,95+19 * 1,075)$
95,00

$\mathbf{2 , 5 0}(\mathbf{U})$

0,00

$\underline{-1,075}$

$\underline{-1,075(F)}$

96,425

95,00

$\underline{1,425(U)}$

\section{Sales \& General Administration}

Exhibit 4 (in appendix ${ }^{13}$ ) provides monthly data on sales \& general administration (S\&GA) costs. These overhead costs are not - or only indirectly -related to production volume but relate to the administration and invoicing of sales orders. These costs not only include the wage of the person responsible for the administration but also all other (variable) costs that are driven by the number of sales orders ${ }^{14}$. Normally, the administration immediately proceeds sales orders to production and a setup and production run follows. S\&GA labour capacity for the year ended was 960 hours, based on the $0,5 \mathrm{fte}$ used throughout the year.

\section{Sales and Revenues}

Carpenter \& Millbridge operates in what it always took to be a "buyer-market". By this is meant that the company always produced exactly the amount its industrial clients wanted, given the company's

\footnotetext{
${ }^{13}$ See also diskette C\&M WA BU.xls

${ }^{14}$ The welding alloys business unit hired one person ( $0,5 \mathrm{fte}$, i.e. full-time equivalent) at a wage rate of $\varepsilon 10 /$ hour.
} 
listed sales price. An overview of the prices set by the company during the past year is given in Exhibit 5 (in appendix ${ }^{15}$ ).

The company has never really tried to use its geographical market power by, for example, playing with the demand function it faces.

\section{Assignments}

Consider the following data on a job order of 1.600 units.

1.400 Units were processed on the SD95-XL machine, 200 units on the SD70-X machine. Actual machine hours used on this job were 27,3 SD95-XL machine hours and 5,4 SD70-X machine hours. Total direct labour hours (for the 1.600 units) amounted to 34,6 hours, not including set-up labour hours of 3,9 hours. For the job both raw materials $\mathrm{R}$ and $\mathrm{S}$ were used: 62,5 kilograms of $\mathrm{R}$ (at a raw material purchase price of $\varepsilon 0,95$ ) and 28,5 kilograms of $\mathrm{S}$ (at a raw material price of $\varepsilon$ $1,05)$ were consumed.

The goods were sold at a price of $\varepsilon$-cent 38,9 .

1. Calculate the SRQV, MV and MSV. Check whether the standard rates mentioned in the main text examples still apply. If they do not, use the ones you think are more appropriate. Explain what you are doing (and why!) and discuss your findings.

2. Calculate estimate profits this job would bring in using (i) "traditional" full cost allocation (volume driven) and (ii) on the basis of an $\mathrm{ABC}$-method. Explain what you are doing and discuss the difference(s) you find.

3. Do you think the sales price of $\varepsilon$-cent 38,9 maximises profits? Estimate demand and caculate maximum expected profits under (i) full-costing and (ii) ABC. Discuss the role of demand elasticity!

4. Discuss the advantages of calculating the SRQV, MV and MSV and the links with activitybased costing (ABC) and Just-in-time management (JIT).

\section{Related literature}

Cheatham, C. \& L.R. Cheatham, 1996, Redesigning Cost systems: Is Standard Costing Obsolete?, Accounting Horizons, December 1996, pp. 23-31

Harrell, H., 1992, Materials Variance Analysis and JIT: A New Approach, Management Accounting, May 1992, pp. 33-38

Johnsen, D. \& P. Sopariwalla, 2000, Standard Costing Is Alive and Well at Parker Brass, Management Accounting Quarterly, Winter 2000, pp. 12-20

${ }^{15}$ See diskette C\&M WA BU.xls 


\section{Appendix}

Carpenter \& Millbridge Ltd. - Welding Alloys BU

Exhibit 1

Weekly production data (exclusive raw material costs)

\begin{tabular}{|c|c|c|c|c|}
\hline Week & $\mathrm{SU}^{16}$ & PROD $^{17}$ & DLH $^{18}$ (hours) & $\mathrm{TPC}^{19}$ \\
\hline 1 & 7 & 14 & 327,25 & $\varepsilon 3.842,50$ \\
\hline 2 & 5 & 11 & 225 & $\varepsilon 2.742,50$ \\
\hline 3 & 3 & 6 & 125,5 & $\varepsilon 1.675,00$ \\
\hline 4 & 4 & 10 & 194,25 & $\varepsilon 2.397,50$ \\
\hline 5 & 6 & 12,5 & 285,25 & $\varepsilon 3.395,00$ \\
\hline 6 & 5 & 9 & 180,75 & $\varepsilon 2.305,00$ \\
\hline 7 & 5 & 9,5 & 184,5 & $\varepsilon 2.355,00$ \\
\hline 8 & 3 & 6,5 & 129,25 & $\varepsilon 1.717,50$ \\
\hline 9 & 5 & 10 & 208,5 & $\varepsilon 2.590,00$ \\
\hline 10 & 7 & 14,5 & 337,75 & $\varepsilon 3.970,00$ \\
\hline 11 & 5 & 10,75 & 235,25 & $\varepsilon 2.862,50$ \\
\hline 12 & 5 & 10 & 202,75 & $\varepsilon 2.522,50$ \\
\hline 13 & 4 & 8 & 167,5 & $\varepsilon 2.132,50$ \\
\hline 14 & 4 & 7,9 & 154 & $\varepsilon 2.005,00$ \\
\hline 15 & 5 & 10,5 & 207 & $\varepsilon 2.565,00$ \\
\hline 16 & 5 & 10 & 208 & $\varepsilon 2.575,00$ \\
\hline 17 & 5 & 10,5 & 215,75 & $\varepsilon 2.655,00$ \\
\hline 18 & 6 & 12 & 272,75 & ع $3.262,50$ \\
\hline 19 & 3 & 5,5 & 112,5 & $\varepsilon 1.542,50$ \\
\hline 20 & 5 & 10 & 194,75 & $\varepsilon 2.452,50$ \\
\hline 21 & 7 & 13,5 & 320,25 & $\varepsilon 3.795,00$ \\
\hline 22 & 5 & 10 & 191,5 & $\varepsilon 2.415,00$ \\
\hline 23 & 5 & 10 & 208,25 & $\varepsilon 2.590,00$ \\
\hline 24 & 5 & 9,75 & 195,5 & $\varepsilon 2.455,00$ \\
\hline 25 & 6 & 12 & 273 & $\varepsilon 3.267,50$ \\
\hline 26 & 3 & 6,2 & 123,75 & $\varepsilon 1.657,50$ \\
\hline 27 & 3 & 5,75 & 120,25 & $\varepsilon 1.627,50$ \\
\hline 28 & 5 & 10 & 198,25 & $\varepsilon 2.480,00$ \\
\hline 29 & 5 & 10 & 196,75 & $\varepsilon 2.470,00$ \\
\hline 30 & 5 & 8 & 155 & $\varepsilon 2.045,00$ \\
\hline 31 & 5 & 10 & 191 & $\varepsilon 2.412,50$ \\
\hline 32 & 5 & 8,75 & 170,25 & $\varepsilon 2.200,00$ \\
\hline 33 & 3 & 5,9 & 120,25 & $\varepsilon 1.617,50$ \\
\hline 34 & 5 & 10 & 193,75 & $\varepsilon 2.435,00$ \\
\hline 35 & 4 & 8,25 & 173 & $\varepsilon 2.195,00$ \\
\hline 36 & 6 & 9 & 183,25 & $\varepsilon 2.372,50$ \\
\hline 37 & 5 & 10,45 & 216 & $\varepsilon 2.665,00$ \\
\hline 38 & 5 & 10 & 208,25 & $\varepsilon 2.575,00$ \\
\hline 39 & 5 & 10 & 208,25 & $\varepsilon 2.590,00$ \\
\hline 40 & 4 & 7,8 & 163,25 & $\varepsilon 2.100,00$ \\
\hline 41 & 4 & 8 & 163,75 & $\varepsilon 2.095,00$ \\
\hline 42 & 6 & 12 & 255,5 & ع 3.102,50 \\
\hline 43 & 5 & 10,1 & 198 & $\varepsilon 2.472,50$ \\
\hline 44 & 7 & 14 & 335,5 & ع $3.927,50$ \\
\hline 45 & 5 & 10 & 203,25 & $\varepsilon 2.540,00$ \\
\hline 46 & 5 & 9,9 & 195,75 & $\varepsilon 2.455,00$ \\
\hline 47 & 5 & 10,55 & 215 & $\varepsilon 2.657,50$ \\
\hline 48 & 7 & 14 & 338,25 & $\varepsilon 3.950,00$ \\
\hline
\end{tabular}

${ }^{16} \mathrm{SU}=$ number of set-ups that week.

${ }^{17} \mathrm{PROD}=$ units of production (in thousands)

${ }^{18}$ DLH: Total Labour Hours, excluding set-up \& maintenance labour hours.

${ }^{19} \mathrm{TPC}=$ Total Production Cost in $\varepsilon$, including weekly (fixed) machine maintenance costs and including direct and indirect (set-up) labour, calculated at constant wage rate of $\varepsilon 10$ per labour hour throughout the whole year. TPC does not include material costs, nor does it include Sales \& General Administration (SGA). 


\section{Carpenter \& Millbridge Ltd. - Welding Alloys BU \\ Exhibit 2 \\ Actual Machine Hours (monthly data)}

\begin{tabular}{ccc} 
Week & machine hours (SD95-XL) & machine hours (SD70-X) \\
\hline $1-4$ & 703,50 & 140,00 \\
$5-8$ & 698,75 & 67,50 \\
$9-12$ & 812,25 & 143,50 \\
$13-16$ & 720,25 & 13,50 \\
$17-20$ & 715,00 & 67,25 \\
$21-24$ & 798,50 & 97,50 \\
$25-28$ & 646,75 & 57,00 \\
$29-32$ & 713,00 & 0,00 \\
$33-36$ & 670,25 & 0,00 \\
$37-40$ & 781,25 & 12,00 \\
$41-44$ & 748,00 & 170,50 \\
$45-48$ & 796,25 & 130,00
\end{tabular}

Carpenter \& Millbridge Ltd. - Welding Alloys BU

Exhibit 3

Actual Material Usage \& Costs (monthly data)

\begin{tabular}{cllll} 
Week & Production $^{20}$ & Raw material $\mathrm{R}^{21}$ & Raw material $\mathrm{S}^{22}$ & $\mathrm{TMC}^{23}$ \\
\hline $1-4$ & 41.000 & 1850,00 & 198,50 & $\varepsilon 1.971$ \\
$5-8$ & 37.500 & $1.850,00$ & 25,40 & $\varepsilon 1.785$ \\
$9-12$ & 45.250 & $1.850,00$ & 417,50 & $\varepsilon 2.207$ \\
$13-16$ & 36.400 & $1.805,00$ & 0,00 & $\varepsilon 1.715$ \\
$17-20$ & 38.000 & $1.895,00$ & 4,90 & $\varepsilon 1.806$ \\
$21-24$ & 43.250 & $1.850,00$ & 308,00 & $\varepsilon 2.089$ \\
$25-28$ & 33.950 & $1.700,00$ & 0,00 & $\varepsilon 1.615$ \\
$29-32$ & 36.750 & $1.840,00$ & 0,00 & $\varepsilon 1.748$ \\
$33-36$ & 33.150 & $1.655,00$ & 0,00 & $\varepsilon 1.572$ \\
$37-40$ & 38.250 & $1.912,50$ & 0,00 & $\varepsilon 1.817$ \\
$41-44$ & 44.100 & $2.142,50$ & 63,00 & $\varepsilon 2.103$ \\
$45-48$ & 44.450 & $1.850,00$ & 390,00 & $\varepsilon 2.177$
\end{tabular}

\section{Carpenter \& Millbridge Ltd. - Welding Alloys BU \\ Exhibit 4}

Actual SG\&A costs (monthly data)

\begin{tabular}{ll} 
Week & S\&GA \\
\hline $1-4$ & $\varepsilon 1.206$ \\
$5-8$ & $\varepsilon 1.201$ \\
$9-12$ & $\varepsilon 1.255$ \\
$13-16$ & $\varepsilon 1.136$ \\
$17-20$ & $\varepsilon 1.164$ \\
$21-24$ & $\varepsilon 1.216$ \\
$25-28$ & $\varepsilon 1.140$ \\
$29-32$ & $\varepsilon 1.189$ \\
$33-36$ & $\varepsilon 1.127$ \\
$37-40$ & $\varepsilon 1.186$ \\
$41-44$ & $\varepsilon 1.204$ \\
$45-48$ & $\varepsilon 1.272$
\end{tabular}

\footnotetext{
${ }^{20}$ Units produced in the 4-week time-span (see exhibit 1).

${ }^{21}$ Actual usage in kilograms.

${ }^{22}$ Actual usage in kilograms

${ }^{23} \mathrm{TMC}=$ Total Material Cost at prices for R and S per kilogram being the same throughout the whole year: $\varepsilon 0,95$ resp. $\varepsilon 1,075$.
} 
Carpenter \& Millbridge Ltd. - Welding Alloys BU

Exhibit 5

Actual Sale Prices and Revenues (monthly data)

\begin{tabular}{lll} 
Week & Sales price $^{24}$ & Revenues \\
\hline $1-4$ & 39,47 & $\varepsilon 16.183$ \\
$5-8$ & 39,94 & $\varepsilon 14.978$ \\
$9-12$ & 38,89 & $\varepsilon 17.598$ \\
$13-16$ & 40,09 & $\varepsilon 14.593$ \\
$17-20$ & 39,87 & $\varepsilon 15.151$ \\
$21-24$ & 39,16 & $\varepsilon 16.937$ \\
$25-28$ & 40,42 & $\varepsilon 13.723$ \\
$29-32$ & 40,04 & $\varepsilon 14.715$ \\
$33-36$ & 40,52 & $\varepsilon 13.432$ \\
$37-40$ & 39,84 & $\varepsilon 15.239$ \\
$41-44$ & 39,05 & $\varepsilon 17.221$ \\
$45-48$ & 39,00 & $\varepsilon 17.336$ \\
& & \\
Total & & $\varepsilon 187.106$
\end{tabular}

${ }^{24}$ Prices in eurocents per unit. 